\title{
Identification of microsatellite markers in coffee associated with resistance to Meloidogyne exigua
}

\author{
T.B. Pereira ${ }^{1}$, T.A. Setotaw ${ }^{1}$, D.N. Santos ${ }^{1}$, A.N.G. Mendes ${ }^{1}$, S.M.L. Salgado ${ }^{2}$, \\ G.R. Carvalho ${ }^{2}$ and R.M. Rezende ${ }^{2}$ \\ ${ }^{1}$ Departamento de Agricultura, Universidade Federal de Lavras, Lavras, \\ MG, Brasil \\ ${ }^{2}$ Unidade Regional do Sul de Minas, \\ Empresa de Pesquisa Agropecuária de Minas Gerais, Lavras, MG, Brasil \\ Corresponding author: T.A. Setotaw \\ E-mail: setotaw2006@gmail.com \\ Genet. Mol. Res. 15 (3): gmr.15038054 \\ Received November 12, 2015 \\ Accepted February 19, 2016 \\ Published July 29, 2016 \\ DOI http://dx.doi.org/10.4238/gmr.15038054
}

Copyright $(2016$ The Authors. This is an open-access article distributed under the terms of the Creative Commons Attribution ShareAlike (CC BY-SA) 4.0 License.

\begin{abstract}
Meloidogyne species are destructive phytonematodes that result in reduced yields of coffee. The classic test for resistance to Meloidogyne exigua in coffee progenies is both expensive and time-consuming. The use of molecular marker techniques can assist the selection process when it is difficult to measure the phenotype, such as in cases of resistance to nematode infestation. The objective of this study was to identify microsatellite markers associated with resistance to $M$. exigua in $\mathrm{F}_{5}$ progenies of coffee derived from a cross between Híbrido de Timor 440-10 and Catuaí Amarelo IAC 86. Of the 44 simple sequence repeat (SSR) markers evaluated, 11 showed a polymorphic pattern with a mean number of 4.5 alleles per marker. Clustering analysis classified 82 progenies into three groups related to
\end{abstract}


the response to nematodes and parental genotypes allocated to different groups (resistant and susceptible). SSRCafé 40 allele 2, SSRCafé 15 allele 3, SSRCafé 20 allele 3, and SSRCafé 13 allele 1 were negatively correlated with reproduction factor. In addition, SSRCafé 13 allele 2, SSRCafé 19 allele 3, SSRCafé 40 allele 2, SSRCafé 15 allele 3, and SSRCafé 20 allele 3 were correlated with the root gall index of M. exigua. These SSR markers, which have been validated in this population, represent a potential method to select progenies resistant to nematodes in coffee-breeding programs.

Key words: Genetic diversity; SSR; Stepwise regression; Nematodes; Coffea arabica

\section{INTRODUCTION}

Brazil is the major producer and exporter of coffee in the world. In 2014, a total of 32 million bags of Coffea arabica and 13 million bags of Coffea canephora were collected from a 2,267,577.8 ha area of coffee plantations (Companhia Nacional de Abastecimento - CONAB, 2014).

Meloidogyne exigua Goeldi 1887 is probably the most widespread species parasitizing the coffee tree in the Americas, which results in yield losses that vary depending upon the cultivar, soil, and environmental conditions involved. The presence of phytonematodes is thought to be the principal factor that limits the growth and productivity of the coffee tree (Barbosa et al., 2008). This microscopic organism is found in the root and affects the development of the whole plant. M. exigua is one of the most important parasitic species predominant in all coffee-producing states of Brazil. This pathogen is also widely distributed in all coffee-growing countries of the world, and results in large losses in productivity (Sasser, 1977). The diverse dissemination and adaptive capability of Meloidogyne species in various regions have resulted in this species being reported in $95 \%$ of the municipality of South of Minas Gerais State (Barbosa et al., 2008). This species causes nutritional changes and reduces the yield of coffee plants due to deficient absorption and translocation of water and nutrients (Barbosa et al., 2008).

Due to the damage caused to coffee plants, farmers continuously seek methods to control nematode. The use of resistant cultivars is the most common and economical viable method of controlling nematode infestation (Alpizar et al., 2007). In this regard, Híbrido de Timor presents resistance to M. exigua and has contributed to the development of coffee cultivars with high productivity (Pereira et al., 2012). Progenies derived from these hybrids possess genes that can modify the phenotype and provide resistance to nematodes (Anthony et al., 2005). Based on this strategy, various cultivars of $C$. arabica have been developed for production in Brazil and provide considerable economic gain for the farmers in these regions (Setotaw et al., 2013).

Study on the inheritance of root-knot nematode resistance in coffee using the $F_{2}$ population revealed that resistance to $M$. exigua is controlled by the simple inheritance of major genes, whereas the gall index exhibited incomplete dominant expression (Noir et al., 2003). Complete dominance of the Meloidogyne species has also been reported in Capsicum annuum (de Souza-Sobrinho et al., 2002) and lettuce (Maluf et al., 2002).

Molecular markers, such as microsatellites or simple sequence repeats (SSR), can be used to select progenies that are resistant to M. exigua as an alternative to the classic method

Genetics and Molecular Research 15 (3): gmr.15038054 
of evaluation, which is both costly and time-consuming (Jenkins et al., 2012). If these markers are evaluated and validated in a population of coffee plants infested with nematodes, and their association with nematode resistance is established, they can be used to evaluate a high number of progenies in a short period. In addition, unlike morphological markers, molecular markers are not influenced by the environment (Machado et al., 2013).

Molecular markers associated with parasitism of the genus Meloidogyne have been used in different crop species. In soybean, Silva et al. (2001) and Fuganti et al. (2004) demonstrated an association between the microsatellite marker SOYHS 176 and the number of galls in Meloidogyne javanica, whereas Jenkins et al. (2012) verified the association of microsatellite markers with the reaction to Meloidogyne incognita in cotton. However, in coffee, only an association between AFLP markers and resistance to the nematode species $M$. exigua has been reported (Noir et al., 2003; Diniz et al., 2005). This highlights the need for more research to identify molecular markers associated with resistance to root-knot nematode in coffee in order to explore the advantage of this technology in the development of coffee cultivars that are resistant to nematodes. In addition, such research would benefit coffee researchers working in different parts of the world.

One of the methods used to identify associations between molecular markers and phenotypic characteristics is stepwise multiple-regression analysis. In this method, all markers evaluated enter the model and stay in the model when conditions set by the researcher are satisfied. Stepwise multiple regression is frequently used to identify molecular markers associated with disease resistance and other agronomic, traits in different crop species (Pereira et al., 2008; Ruan et al., 2009).

Research leading to the development of $M$. exigua-resistant cultivars by combining conventional breeding with biotechnology are rare in coffee-breeding programs; therefore, the present study represents the first to investigate the association of microsatellite markers with resistance to Meloidogyne species. Here, a strong correlation was observed between molecular markers and resistance to nematodes, highlighting the potential use of these markers to select progenies resistant to nematodes in breeding programs. Therefore, these results may contribute significantly to the advancement of genetic improvement in coffee, especially in the production of cultivars that are resistant to nematodes in Brazil as well as in other coffee-growing countries.

Therefore, the objective of this study was to identify microsatellite markers associated with resistance to the nematode $M$. exigua in the $\mathrm{F}_{5}$ progenies of coffee seedlings derived from the hybridization of Híbrido de Timor 440-10 and Catuaí Amarelo IAC 86.

\section{MATERIAL AND METHODS}

\section{Progenies}

Molecular analyses were performed in the Plant Biotechnology Laboratory of Agricultural Research Company of Minas Gerais localized in the EPAMIG, Caldas, Minas Gerais. Phenotypic analyses were performed in the EPAMIG/UFLA in Lavras-Minas Gerais in a greenhouse and in the nematology laboratory.

Eighty-two $\mathrm{F}_{5}$ progenies of coffee seedlings derived from a cross between Híbrido de Timor 440-10 (resistant progeny of C. canephora var. robusta x C. arabica) and Catuaí Amarelo 86 (susceptible progeny of $C$. arabica cultivar) belonging to the coffee-breeding program of EPAMIG in Minas Gerais (Rezende et al., 2013) were used in this study (Table 1).

Genetics and Molecular Research 15 (3): gmr.15038054 
Table 1. Identification of standard Coffea arabica cultivars and $\mathrm{F}_{5}$ progenies selected based on the response to nematodes in fields naturally infected with Meloidogyne exigua.

\begin{tabular}{|c|c|c|c|}
\hline Identification & Progenies & Identification & Progenies \\
\hline 1 & Híbrido de Timor 440-10* & 43 & 514-7-16-C208-B1P3 \\
\hline 2 & Catuaí Amarelo IAC 86* & 44 & 514-7-16-C208-B1P4 \\
\hline 3 & 514-7-4-C130-B1P1 & 45 & 514-7-16-C208-B1P6 \\
\hline 4 & 514-7-4-C130-B1P4 & 46 & 514-7-16-C208-B1P7 \\
\hline 5 & 514-7-4-C130-B1P6 & 47 & 514-5-2-C494-B1P7 \\
\hline 6 & 514-7-16-C208-B1P3 & 48 & 514-7-14-C73-B2P2 \\
\hline 7 & 514-7-16-C208-B1P4 & 49 & $514-7-4-\mathrm{C} 130-\mathrm{B} 2 \mathrm{P} 3$ \\
\hline 8 & 514-7-16-C208-B1P6 & 50 & 514-7-4-C130-B2P4 \\
\hline 9 & 514-7-16-C208-B1P7 & 51 & 514-7-4-C130-B2P5 \\
\hline 10 & 514-5-2-C494-B1P7 & 52 & 514-7-4-C130-B2P6 \\
\hline 11 & 514-7-14-C73-B2P2 & 53 & $514-7-16-\mathrm{C} 208-\mathrm{B} 2 \mathrm{P} 2$ \\
\hline 12 & 514-7-4-C130-B2P3 & 54 & 514-7-16-C208-B2P3 \\
\hline 13 & 514-7-4-C130-B2P4 & 55 & 514-7-16-C208-B2P4 \\
\hline 14 & 514-7-4-C130-B2P5 & 56 & 514-7-16-C208-B2P5 \\
\hline 15 & 514-7-4-C130-B2P6 & 57 & 514-5-2-C494-B2P6 \\
\hline 16 & 514-7-16-C208-B2P2 & 58 & 514-5-2-C494-B2P7 \\
\hline 17 & 514-7-16-C208-B2P3 & 59 & 514-5-2-C494-B2P8 \\
\hline 18 & 514-7-16-C208-B2P4 & 60 & 514-7-14-C73-B3P1 \\
\hline 19 & 514-7-16-C208-B2P5 & 61 & 514-7-14-C73-B3P5 \\
\hline 20 & 514-5-2-C494-B2P6 & 62 & 514-7-4-C130-B3P2 \\
\hline 21 & 514-5-2-C494-B2P7 & 63 & 514-7-4-C130-B3P3 \\
\hline 22 & 514-5-2-C494-B2P8 & 64 & 514-7-4-C130-B3P5 \\
\hline 23 & 514-7-14-C73-B3P1 & 65 & 514-7-16-C208-B3P1 \\
\hline 24 & 514-7-14-C73-B3P5 & 66 & 514-7-16-C208-B3P3 \\
\hline 25 & 514-7-4-C130-B3P2 & 67 & 514-7-16-C208-B3P4 \\
\hline 26 & 514-7-4-C130-B3P3 & 68 & 514-7-8-C364-B3P2 \\
\hline 27 & 514-7-4-C130-B3P5 & 69 & 514-7-8-C364-B3P4 \\
\hline 28 & 514-7-16-C208-B3P1 & 70 & 514-5-2-C494-B3Р3 \\
\hline 29 & 514-7-16-C208-B3P3 & 71 & 514-5-2-C494-B3Р6 \\
\hline 30 & 514-7-16-C208-B3P4 & 72 & 514-7-4-C130-B4P2 \\
\hline 31 & 514-7-8-C364-B3P2 & 73 & 514-7-16-C208-B4P1 \\
\hline 32 & 514-7-8-C364-B3P4 & 74 & 514-7-16-C208-B4P6 \\
\hline 33 & 514-5-2-C494-B3P3 & 75 & 514-5-2-C494-B4P4 \\
\hline 34 & 514-5-2-C494- В3Р6 & 76 & 514-5-2-C494-B4P5 \\
\hline 35 & 514-7-4-C130-B4P2 & 77 & 514-7-4-C130-B4P4 \\
\hline 36 & 514-7-16-C208-B4P1 & 78 & 514-7-6-C208-B1P6 \\
\hline 37 & 514-7-16-C208-B4P6 & 79 & 514-7-16-C208-B1P7 \\
\hline 38 & 514-5-2-C494-B4P4 & 80 & 514-5-2-C494-B1P7 \\
\hline 39 & 514-5-2-C494-B4P5 & 81 & 514-7-4-C130-B2P3 \\
\hline 40 & 514-7-4-C130-B1P1 & 82 & 514-5-2-C494-B2P7 \\
\hline 41 & 514-7-4-C130-B1P4 & 83 & 514-7-14-C73-B3P1 \\
\hline 42 & 514-7-4-C130-B1P6 & 84 & 514-7-4-C13-B3P5 \\
\hline
\end{tabular}

*Parents used as control. C, pit; B, block; P, plant.

\section{Evaluation of resistance to $M$. exigua}

Progenies derived from a cross between Híbrido de Timor 440-10 and Catuaí Amarelo 86 (Table 1) were planted in a greenhouse and seedlings were established in $850-\mathrm{cm}^{3}$ plastic sacks containing soil and manure at a 3:1 ratio and disinfected with dazomet $\left(\right.$ Basamid $\left.^{\mathbb{\circledR}}\right)(\mathrm{BASF}$ Corporation, Florham Park, NJ, USA). In each plastic sack, one $\mathrm{F}_{5}$ plant was planted and used to evaluate the response to nematodes and to collect leaf samples for molecular analyses.

The inoculum was obtained from the roots of coffee plants from a naturally infested farm in the municipality of Campos Altos. Eggs were extracted from the root according to the technique described by Hussey and Barker (1973) and subsequently used to prepare the inoculum. The egg suspension was calibrated with the aid of a light microscope using Peters' slides. To confirm the identity of the nematode species, females isolated from the galls 
were identified using isoenzyme analysis (Carneiro and Almeida, 2001) with M. exigua E1 phenotype $(\mathrm{Rm}=1.5)$. When the seedling had 4-6 pairs of leaves, they were inoculated with 5000 eggs of $M$. exigua around the root.

To evaluate the response to nematodes after 320 days of inoculation, eggs and juvenile M. exigua were extracted from the roots using $0.5 \% \mathrm{NaOCl}$, according to the method described by Hussey and Barker (1973). The size of the nematode population was estimated under a light microscope using Peters' slides. Then, the reproduction factor was estimated from the ratio of the final population density and initial density (Seinhorst, 1967), by account of three replicates.

The index of galls was recorded using a scale of 0 to 5 based on the number of galls in three replicates $(0=$ absence of galls, $1=1-2$ galls, $2=3-10,3=11-30,4=31-100,5=>100$ galls) according to the method recommended by Hartman and Sasser (1985).

\section{DNA extraction and quantification}

Completely expanded leaves were collected from $\mathrm{F}_{5}$ progenies and control seedlings, and transported to the laboratory where they were stored in a deep freezer $\left(-80^{\circ} \mathrm{C}\right)$ until subsequent lyophilization and DNA extraction. DNA was extracted according to the methodology described by Nunes et al. (2011).

To verify the quality of DNA, samples were visualized under UV light after electrophoresis on $0.7 \%$ agarose gel in the presence of ethidium bromide. DNA was quantified at $260 \mathrm{~nm}$ using an NIR spectrophotometer. The quality of DNA was estimated using a 260/280 $\mathrm{nm}$ ratio, and samples with a ratio of 1.5-2.0 were considered adequate for further analysis. Finally, samples were standardized to $50 \mathrm{ng} / \mu \mathrm{L}$ for further analysis.

\section{Microsatellite markers}

Forty-four microsatellite markers believed to be polymorphic for $C$. arabica species were tested in this study (Table S1).

PCR was performed in a volume of $25 \mu \mathrm{L}$, containing $50 \mathrm{ng}$ DNA, $6 \mu \mathrm{L} 5 \mathrm{X}$ reaction buffer, $1 \mathrm{mM} \mathrm{MgCl}, 150 \mu \mathrm{M}$ each dNTP, $0.1 \mu \mathrm{M}$ primers, and $0.6 \mathrm{U}$ Taq DNA polymerase (Go Taq Flexi, Promega, Madison, WI, USA). Reactions were carried out in a gradient thermocycler (Multigene Gradient, Labnet International, USA) using touchdown PCR with the following program: $94^{\circ} \mathrm{C}$ for a 2-min initial denaturing, followed by 13 cycles at $94^{\circ} \mathrm{C}$ for $30 \mathrm{~s}$; annealing temperature $67^{\circ}-55^{\circ} \mathrm{C}$ for $30 \mathrm{~s}$, reducing $1^{\circ} \mathrm{C}$ in each cycle, extension at $72^{\circ} \mathrm{C}$ for $30 \mathrm{~s}$. This was followed by 30 cycles of denaturation at $94^{\circ} \mathrm{C}$ for $30 \mathrm{~s}, 55^{\circ} \mathrm{C}$ for $30 \mathrm{~s}$, and extension at $72^{\circ} \mathrm{C}$ for $30 \mathrm{~s}$. A final extension occurred at $72^{\circ} \mathrm{C}$ for $8 \mathrm{~min}$.

The amplification products were subjected to denatured gel electrophoresis on $6 \%$ polyacrylamide gel at $60 \mathrm{~W}$ power for variable times according to the size of the alleles. Next, bands were visualized using silver nitrate according to the method described by Setotaw et al. (2010). The gel was then dried overnight at room temperature and photographed.

\section{Statistical analysis}

For each microsatellite marker, each amplified fragment was coded 1 for the presence or 0 for the absence of each band. To study genetic diversity among progenies of coffee, the Jaccard coefficient of similarity (Jaccard, 1908) was estimated using the GENES statistical 
programs (Cruz, 2013). A dendrogram was produced using MEGA 6.06 (Tamura et al., 2013) based on the Jaccard genetic distance (1-Jaccard coefficient of similarity), using the unweighted pair group method with arithmetic average (UPGMA) method with the objective of clustering the progenies in their respective groups. Principal coordinate analysis (PCoA) was performed using GenAlex 6.2 (Peakall and Smouse, 2006) based on the Jaccard genetic distance. In this analysis, the genetic distance matrix was used to produce the coordinate of the graphs where the progenies were represented as points in the Cartesian plane.

\section{Identification of microsatellite markers associated with resistance to $M$. exigua}

Polymorphic microsatellite markers were grouped as being positively or negatively associated, based on the Pearson correlation, with the nematode reaction (reproduction factor and gall index). The Pearson correlation coefficient was estimated using the GENES statistical analysis program (Cruz, 2013).

Thereafter, associations between microsatellite markers and parameters related to parasitism were determined using stepwise multiple-regression analysis with the objective of identifying microsatellite markers related to the response to nematodes in the progenies. The quantitative index of parasitism was considered as the dependent variable and the positive and negative markers as independent variables. A significance level of 0.15 was used as the criteria for the marker to enter and remain in the model. Stepwise regression analysis was carried out using the PROCGLM program of Statistical Analysis System (SAS Institute, 2004) to identify the markers associated with phenotypic characteristics.

\section{RESULTS}

Among the primers used in the $\mathrm{F}_{5}$ progenies, only 11 showed a polymorphic pattern among the parental genotypes, these were as follows: SSRCafé 4, SSRCafé 13, SSRCafé 14, SSRCafé 15, SSRCafé 19, SSRCafé 20, SSRCafé32, SSRCafé 37, SSRCafé 39, SSRCafé 40, and SSRCafé 41. The primers produced 2-8 polymorphic alleles among progenies with an average 4.5 alleles per primer (Table 2 ).

Table 2. Polymorphic microsatellite markers, number of polymorphic alleles, and percentage polymorphism among the Coffea arabica progenies.

\begin{tabular}{l|l|l|c|c}
\hline Code & Marker name & Reference & No. of alleles & Polymorphism (\%) \\
\hline SSRCafé 4 & SSRCa087 & Missio et al. (2009) & 5 & 80.0 \\
\hline SSRCafé 13 & CFGA792b & Cristancho and Gaitan (2008) & 7 & 85.7 \\
\hline SSRCafé 14 & CFCA281 & Cristancho and Gaitan (2008) & 4 & 100.0 \\
\hline SSRCafé 15 & CFGA627 & Cristancho and Gaitan (2008) & 6 & 50.0 \\
\hline SSRCafé 19 & CFCA360 & Cristancho and Gaitan (2008) & 3 & 66.0 \\
\hline SSRCafé 20 & AJ250254 & Combes et al. (2000) & 4 & 100.0 \\
\hline SSRCafé 32 & AJ308819 & Rovelli et al. (2000) & 4 & 700.0 \\
\hline SSRCafé 37 & BQ448809 & Rovelli et al. (2000) & 2 & 7 \\
\hline SSRCafé 39 & EU597602 & López-Gartner et al. (2009) & 7 & 100.0 \\
\hline SSRCafé 40 & EU597603 & López-Gartner et al. (2009) & 8 & 100.0 \\
\hline SSRCafé 41 & EU597604 & López-Gartner et al. (2009) & & 100.0 \\
\hline
\end{tabular}

Jaccard similarity coefficient compares the number of common alleles present and the total number of alleles involved without considering the number of common alleles that are absent (Jaccard, 1908). The progenies evaluated in this study were grouped into three

Genetics and Molecular Research 15 (3): gmr.15038054 
clusters using the UPGMA clustering method based on the Jaccard genetic distance (1-Jaccard similarity coefficient) (Figure 1). The result revealed high genetic variability among the progenies and verified the efficiency of microsatellite markers for their classification.

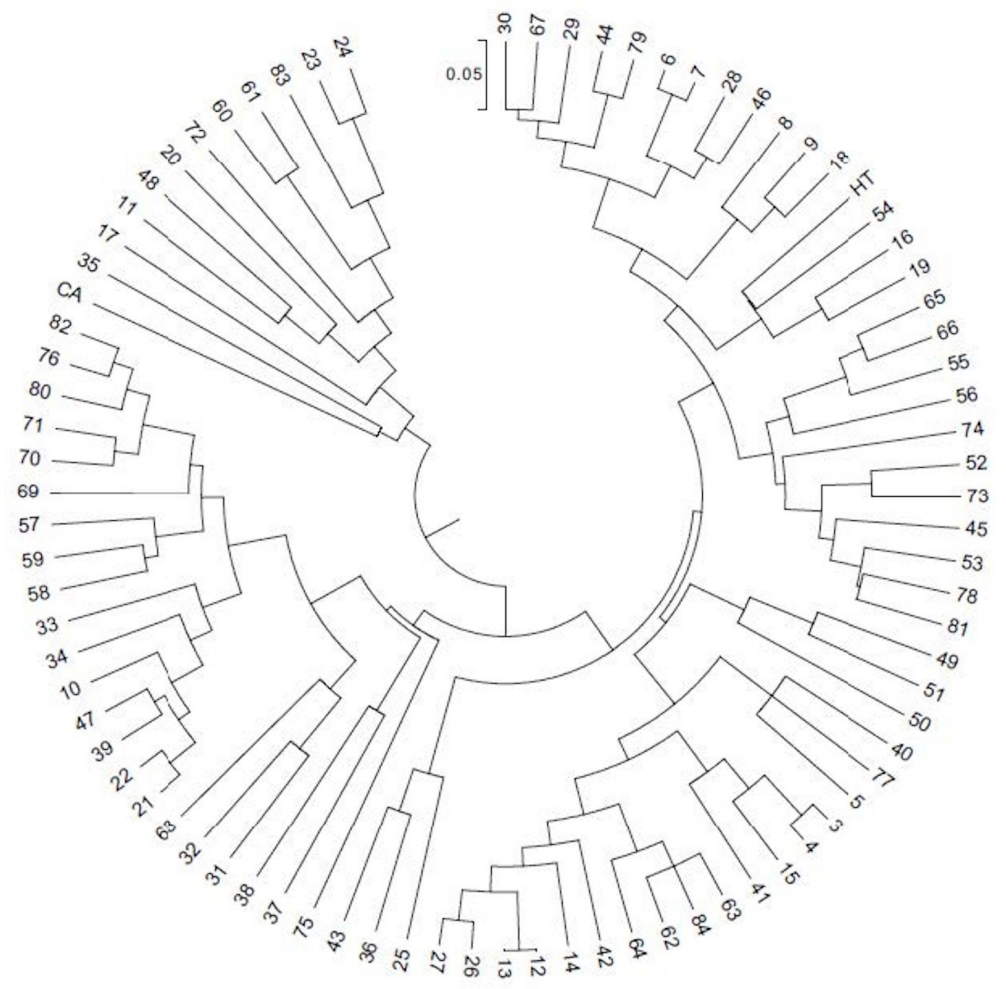

Figure 1. Dendrogram produced using the unweighted pair group method with arithmetic average (UPGMA) clustering method based on the Jaccard genetic dissimilarity coefficient obtained using microsatellite markers.

The progenies with identification numbers 12 and 13 showed a high level of similarity and a high number of common alleles. Both progenies were obtained from the same plant through selfing. In addition, these genotypes were immune to the effects of $M$. exigua and presented reproduction factors of 0 .

The cluster group with the highest number of progenies included the cultivar Híbrido de Timor. Progenies included in this group showed resistant or displayed low reproduction factor for M. exigua, similar to Híbrido de Timor. Group III was also of interest as approximately $90 \%$ of the progenies presented a score of 0 for the gall index and exhibited an immune reaction and resistance to the reproduction factor of M. exigua. This observation is of interest since microsatellite markers were able to group a large number of resistant genotypes into the same cluster.

The resistant (Híbrido de Timor 440-10) and susceptible (Catuaí IAC 86) genotype standards presented resistant and susceptible responses, respectively, and were classified in distinct groups. Of note, the $\mathrm{F}_{5}$ progenies are derived from the same cross, which demonstrates high genetic diversity among the parental lines.

Genetics and Molecular Research 15 (3): gmr.15038054 
The information obtained from the PCoA, is consistent with the data observed on the dendrogram, and showed the genetic relationship of the populations (Figure 2). In general, the majority of genotypes is more similar to Híbrido de Timor and lay below coordinate 2. Conversely, cultivar Catuaí Amarelo IAC 86 was isolated and separated from the other progenies. The progeny with identification number 72 was positioned near to Catuaí and presented a similarly high level of susceptibility to nematodes.

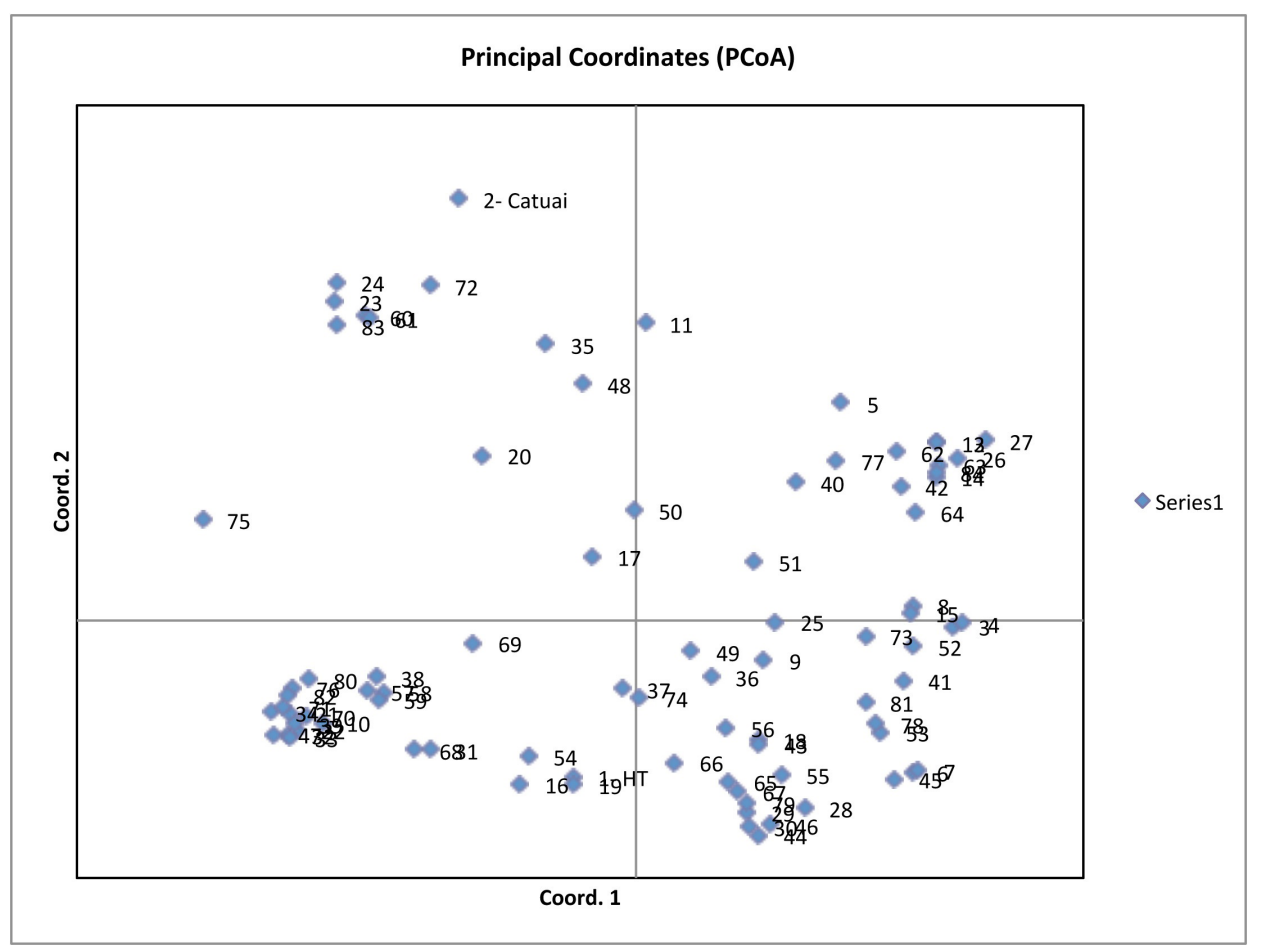

Figure 2. Principal coordinate analysis of $82 \mathrm{~F}_{5}$ progenies and parental genotypes (Catuaí Amarelo IAC 86 and Híbrido de Timor 440-10) using microsatellite markers.

The first two principal coordinates explained $37.03 \%$ of the total variation whereby the first and second explained 21.11 and $15.92 \%$, respectively. This showed that the first principal coordinates explained a low percentage of variability.

Based on the results obtained from the molecular and statistical analyses, it is possible to conclude that the progenies presented high genetic diversity and were clustered in different groups, especially in relation to their response to nematodes. This suggests that it might be possible to identify molecular markers that correlate with resistance to M. exigua.

Pearson correlation coefficient revealed associations between SSR markers and nematode parasitism in $\mathrm{F}_{5}$ progenies. Based on the Pearson correlation coefficient, the markers were classified as being positively or negatively correlated with nematode resistance. The markers significantly correlated with the nematode response were subjected to stepwise regression analysis in order to select the microsatellite markers related to nematode resistance.

Stepwise regression revealed a significant relationship among the SSR markers and the

Genetics and Molecular Research 15 (3): gmr.15038054 
response to nematode infestation among the progenies (Table 3 ). The microsatellite markers SSRCafé 32 allele 2 (96 bp), SSRCafé13 allele 5 (125 bp), SSRCafé 41 allele 5 (90 bp), and SSRCafé 20 allele 1 (130 bp) were positively correlated with reproduction factor and shown to have a significant effect on resistance to $M$. exigua among the $\mathrm{F}_{5}$ progenies. Therefore, the alleles amplified by these markers were associated with high levels of reproduction factor or high susceptibility of the plant. These markers explained $28.43 \%$ of the total phenotypic variation (Table 3). The SSRCafé 32 allele 2 (96 bp) explained a high phenotypic proportion $\left(\mathrm{R}^{2}\right)$ of both parameters related to nematode parasitism. The markers positively correlated with the phenotype can be used in breeding programs for marker-assisted selection (MAS) with the objective of culling progenies presenting specific alleles.

Table 3. Microsatellite markers associated with the reproduction factor of Meloidogyne exigua in $\mathrm{F}_{5}$ progenies of Coffea arabica.

\begin{tabular}{l|l|c|c|c|c}
\hline Correlation & Marker & F value & $\mathrm{R}^{2}(\%)$ & $\mathrm{R}^{2}$ accumulated (\%) & Molecular weight (bp) \\
\hline Positive & SSRCafé 32 allele 2 & $14.90^{*}$ & 15.87 & 15.87 & 96 \\
\hline & SSRCafé 13 allele 5 & $10.86^{* *}$ & 5.92 & 21.78 & 125 \\
\hline & SSRCafé 41 allele 5 & $8.83^{* *}$ & 3.81 & 25.59 & 90 \\
\hline & SSRCafé 20 allele 1 & $7.55^{* *}$ & 2.83 & 28.43 & 130 \\
\hline Negative & SSRCafé 13 allele 1 & $10.13^{* *}$ & 11.36 & 1.36 & 155 \\
\hline & SSRCafé 20 allele 3 & $8.14^{* *}$ & 5.90 & 22.55 & 100 \\
\hline & SSRCafé 40 allele 2 & $7.47^{*}$ & 5.30 & 27.20 & 190 \\
\hline & SSRCafé 15 allele 3 & $7.10^{*}$ & 4.60 & & 190 \\
\hline
\end{tabular}

$* * * \mathrm{P}<0.001$ and $\mathrm{P}<0.0001$, respectively; $\mathrm{R}^{2}$, coefficient of determination.

For the gall index, besides SSRCafé 32 (96 bp), markers SSRCafé 19 allele 2 (130 bp), SSRCafé 20 allele 1 (130 bp), SSRCafé 37 allele 2 (260 bp), SSRCafé 39 allele 1 (100 bp), and SSRCafé 13 allele 5 (125 bp) were positively correlated with parasitism (Table 4) with a combined coefficient of determination of $38.92 \%$. Microsatellite markers SSRCafé 20 allele 3 (100 bp), SSRCafé 40 allele 2 (250 bp), and SSRCafé 15 allele 3 (190 bp) presented significant negative correlations with both of the characters evaluated related to $M$. exigua. SSRCafé 20 allele 3 and SSRCafé 19 allele 3 demonstrated negative correlations with gall index and explained a high percentage of phenotypic variation (Table 4).

Table 4. Microsatellite markers associated with gall index of Meloidogyne exigua in $\mathrm{F}_{5}$ progenies of Coffea arabica.

\begin{tabular}{l|l|c|c|c|c}
\hline Correlation & Marker & F value & $\mathrm{R}^{2}(\%)$ & Accumulated $\mathrm{R}^{2}(\%)$ & Molecular weight (bp) \\
\hline Positive & SSRCafé 32 allele 2 & $11.22^{* *}$ & 12.44 & 12.44 & 96 \\
\hline & SSRCafé 19 allele 2 & $9.70^{*}$ & 7.47 & 19.91 & 130 \\
\hline & SSRCafé 20 allele 1 & $9.62^{*}$ & 7.35 & 27.26 & 130 \\
\hline & SSRCafé 37 allele 2 & $9.24^{* *}$ & 5.46 & 32.73 & 160 \\
\hline & SSRCafé 39 allele 1 & $8.82^{* *}$ & 4.30 & 37.02 & 100 \\
\hline & SSRCafé 13 allele 5 & $7.86^{* *}$ & 1.90 & 38.92 & 11.76 \\
\hline & SSRCafé 13 allele 2 & $10.53^{*}$ & 11.76 & 23.31 & 150 \\
\hline & SSRCafé 20 allele 3 & $11.85^{* *}$ & 11.76 & 32.48 & 118 \\
\hline & SSRCafé 19 allele 3 & $12.35^{* *}$ & 9.18 & 36.38 & 250 \\
\hline & SSRCafé 40 allele 2 & $10.86^{* *}$ & 3.89 & 39.93 & 190 \\
\hline & SSRCafé 15 allele 3 & $9.97^{* *}$ & 3.55 & & \\
\hline
\end{tabular}

$* * * \mathrm{P}<0.001$ and $\mathrm{P}<0.0001$, respectively; $\mathrm{R}^{2}$, coefficient of determination.

\section{DISCUSSION}

Low polymorphism of molecular markers among progenies of $C$. arabica is well documented (Lashermes et al., 1999; Bertrand et al., 2001), since this species has a narrow 
genetic base, is autogamous in nature, tetraploid (Cristancho and Gaitan, 2008), and has a low frequency of microsatellite regions in the genome (Cristancho and Gaitan, 2008; AlMurish et al., 2013). Furthermore, in this case, all progenies originated from the crossing of two genotypes. Low polymorphism was also reported by Combes et al. (2000), who only identified five polymorphic microsatellite markers among 11 SSR primers tested in C. arabica. Furthermore, Cristancho and Gaitan (2008) also identified five polymorphic markers among 12 SSR markers tested in tetraploid Coffea.

In this study, 4.5 polymorphic alleles per marker were observed among the $\mathrm{F}_{5}$ coffee progenies. The number of polymorphic alleles in a population depends on the population size, its genetic constitution, and the different microsatellite markers used. Missio et al. (2009) reported similar results (with 5.1 polymorphic alleles per marker) among coffee cultivars. They also verified the existence of high levels of genetic diversity among genotypes evaluated using PCoA, which is an important and desirable characteristic for breeding programs, as it is needed to increase the genetic base of the breeding population. Even if their occurrence is low in C. arabica, the efficiency of microsatellite markers for the study of genetic diversity in this species has been reported (Missio et al., 2009; Setotaw et al., 2010), consistent with the results of the present study.

Of note, the use of PCoA in the present study revealed high divergence between the Catuaí cultivar and other progenies studied. This may be explained by previous selection pressures on the coffee progenies in areas infested with M. exigua, in which highly susceptible progenies were possibly eliminated.

The results of the PCoA verified that the first two principal coordinates explained a low percentage of variability among the progenies studied. Similar results were reported by Souza et al. (2013) using microsatellite markers that explained $24.9 \%$ of the total variation among the germplasm of $C$. canephora found in Brazil. In contrast to our findings, Setotaw et al. (2010) were able to explain $67 \%$ of the total variation from the first two principal coordinates obtained using amplified fragment length polymorphism (AFLP) and random-amplified polymorphic DNA (RAPD) molecular markers. These results can be explained by the high levels of polymorphism identified by RAPD and AFLP. In addition, the population used consisted of Híbrido de Timor, which contains higher genetic variability than the population used in the present study.

The aim of the stepwise regression analysis was to select SSR markers that had high percentage of contribution and were associated with the nematode reaction in $\mathrm{F}_{5}$ progenies in this study. Stepwise regression analysis was used to identify molecular markers associated with resistance and agronomic characteristics in different crops (Silva and Vencovsky, 2002). Ruan et al. (2009) successfully applied stepwise regression to study the association between molecular markers and dryness caused by disease in Hippophae L. Pereira et al. (2008) used stepwise regression analysis to identify quantitative trait loci linked to grain productivity in common bean. Missio et al. (2011) used stepwise regression to associate microsatellite markers with the response of different genotypes of coffee to leaf rust. This method also proved to be efficient when used to identity microsatellite markers associated with nematode resistance in the present study.

The negative correlation found between some markers and the evaluated characters is of interest, since this demonstrates the presence of an allele that is associated with the low value of the parameter related to the disease, or, in other words the progenies resistant to $M$. exigua. The microsatellite markers negatively correlated with both characteristics associated 
with nematode resistance were SSRCafé 20 allele 3, SSRCafé 15 allele 3, and SSRCafé 40 allele 2. Fuganti et al. (2004) identified two microsatellite markers, named Satt 144 and SOYHSP 176, which were correlated with the gall number and infestation scores of M. javanica in soybean. Ruan et al. (2009) identified inter-simple sequence repeat markers associated with disease resistance in Hippophae L. Chen et al. (2012) used multiplex PCR to identify molecular markers linked to root-knot nematode resistance in tomato, and identified a specific marker (Mi).

The coefficient of determination of each marker could have been affected by the low number of primers used. Another difficulty when studying nematode resistance is the high morphological and chromosomal variations present among individuals within the same species, with the possibility of pathotypes and races that can disrupt the genetic resistance of the plant (Medina Filho et al., 2008). This makes it necessary to evaluate the resistance of progenies infested with different nematode populations. In our study, the SSR markers SSRCafé 20 allele 3 , SSRCafé 15 allele 3 , and SSRCafé 40 allele 2 were significantly negatively correlated with reproduction factor and gall index, and produced a reasonable coefficient of determination. Therefore, they may be used as indirect criteria for the selection of genotypes tolerant to rootknot nematode in Coffee arabica.

This study also showed that Híbrido de Timor is an important source of resistance genes to diseases and pests, including nematode, since we were able to identify various progenies with resistance to nematodes, which can be released as cultivars in the near future. Setotaw et al. (2013) reported the development of $C$. arabica cultivars using Híbrido de Timor as a source of genes for resistance to pests and diseases, and their release for commercial production in Brazil.

The combined use of the markers selected in this study can lead to the successful selection of genotypes that carry genes conferring resistance to M. exigua in coffee, since the combined coefficient of determination from these markers is satisfactory. We recommend that the markers selected in this study are validated in other coffee progenies and nematode populations for potential future use in breeding programs as MAS. The validation of these markers should be performed in a population with a variable response to nematodes. In addition, the results obtained in this study will facilitate the selection process in breeding programs of coffee related to nematode resistance, which require labor and time.

In addition, the research outputs presented in this report not only serve the breeding program in Brazil, but also the international coffee breeder working to develop nematoderesistant coffee cultivars. The results of this study show that it is possible to identify SSR markers associated with nematode resistance, which should encourage others to undertake similar research and obtain further information on this subject, which is important for coffeebreeding programs throughout the world.

\section{Conflicts of interest}

The authors declare no conflict of interest.

\section{ACKNOWLEDGMENTS}

The authors would like to thank Conselho Nacional de Desenvolvimento Científico e Tecnológico $(\mathrm{CNPq})$ for providing a fellowship to T.B. Pereira. Research supported by Instituto de Ciência e Tecnologia do Café and Consórcio Brasileiro de Pesquisa e Desenvolvimento do Café (CBP\&D/Café).

Genetics and Molecular Research 15 (3): gmr.15038054 


\section{REFERENCES}

Al-Murish TM, Elshafei AA, Al-Doss AA and Barakat MN (2013). Genetic diversity of coffee (Coffea arabica L.) in Yemen via SRAP, TRAP and SSR markers. J. Food Agric. Environ. 11: 411-416.

Alpizar E, Etienne H and Bertrand B (2007). Intermediate resistance to Meloidogyne exigua root-knot nematode in Coffea arabica. Crop Prot. 26: 903-910. http://dx.doi.org/10.1016/j.cropro.2006.08.018

Anthony F, Topart P, Martinez A, Silva M, et al. (2005). Hypersensitive-like reaction conferred by the Mex-1 resistance gene against Meloidogyne exigua in coffee. Plant Pathol. 54: 476-482. http://dx.doi.org/10.1111/j.13653059.2005.01239.x

Barbosa DHSG, Vieira HD and Souza RM (2008). Avaliação em Campo de Cultivares de Coffea arabica em áreas isenta ou infestada por Meloidogyne exigua na Região Noroeste Fluminense -1. Formação da Lavoura. Nematol. Bras. 32: 101-110.

Bertrand B, Etienne H and Eskes AB (2001). Growth, production and bean quality of Coffea arabica as affected by interspecific grafting: consequences for rootstock breeding. Hortic. Sci. (Prague) 36: 269-273.

Carneiro RMDG and Almeida MRA (2001). Técnicas de eletroforese usada no estudo de enzimas dos nematoides de galhas para identificação de espécies. Nematol. Bras 25: 35-44.

Chen SX, Du JN, Hao LN, Wang CY, et al. (2012). Identification of markers tightly linked to tomato yellow leaf curl disease and root-knot nematode resistance by multiplex PCR. Genet. Mol. Res. 11: 2917-2928. http://dx.doi. org/10.4238/2012.July. 10.4

Combes MC, Andrzejewski S, Anthony F, Bertrand B, et al. (2000). Characterization of microsatellite loci in Coffea arabica and related coffee species. Mol. Ecol. 9: 1178-1180. http://dx.doi.org/10.1046/j.1365-294x.2000.00954-5.x

CONAB (Companhia Nacional de Abastecimento) (2014). Acompanhamento da safra brasileira de café: safra 2014: quarta estimativa. Brasília: CONAB.

Cristancho MA and Gaitan AL (2008). Isolation, characterization and amplification of simple sequence repeat loci in coffee. Crop Breed. Appl. Biotechnol. 8: 321-329. http://dx.doi.org/10.12702/1984-7033.v08n04a10

Cruz CD (2013). GENES: a software package for analysis in experimental statistics and quantitative genetics. Acta Scientiarum 35: 271-279.

de Souza-Sobrinho F, Maluf WR, Gomes LAA and Campos VP (2002). Inheritance of resistance to Meloidogyne incognita race 2 in the hot pepper cultivar Carolina Cayenne (Capsicum annuum L.). Genet. Mol. Res. 1: 271-279.

Diniz LEC, Sakiyama NS, Lashermes P, Caixeta ET, et al. (2005). Analysis of AFLP markers associated to the Mex-1 resistance locus in Icatu progenies. Crop Breed. Appl. Biotechnol. 5: 387-393. http://dx.doi.org/10.12702/1984-7033. $\mathrm{v} 05 \mathrm{n} 04 \mathrm{a} 03$

Fuganti R, Beneventi MA, Silva JFV, Arrabalarias CA, et al. (2004). Identificação de marcadores moleculares microssatélites para seleção de genótipos de soja resistentes a Meloidogyne javanica. Nematol. Bras. 28: 125-130.

Hartman KM and Sasser JN (1985). Identification of Meloidogyne species on the basis of differential host test and perineal pattern morphology. In: An advanced treatise on Meloidogyne: methodology (Barker KR, Carter CC and Sasser JN (eds.). Raleigh: North Carolina State University, 69-77.

Hussey RS and Barker KR (1973). A comparison of methods of collecting inocula of Meloidogyne spp. including a new technique. Plant Dis. Rep 57: 1025-1028.

Jaccard P (1908). Nouvelles recherches sur la distribution florale. Bull. Soc. Vaud. Sci. Nat. 44: 223-270.

Jenkins JN, McCarty Jr JC, Wubben MJ, Hayes R, et al. (2012). SSR markers for marker assisted selection of root-knot nematoide (Meloidogyne incognita) resistant plans in cotton (Gossypium hirsutum L.). Euphytica 183: 49-54. http:// dx.doi.org/10.1007/s10681-011-0470-6

Lashermes P, Combes MC, Robert J, Trouslot P, et al. (1999). Molecular characterisation and origin of the Coffea arabica L. genome. Mol. Gen. Genet. 261: 259-266. http://dx.doi.org/10.1007/s004380050965

López-Gartner G, Cortina H, McCouch SR and Moncada MDP (2009). Analysis of genetic structure in a sample of coffee (Coffea arabica L.) using fluorescent SSR markers. Tree Genet. Genomes 5: 435-446.

Machado EL, Silva AS, Santos AS, Bastos LA, et al. (2013). Dissimilaridade genética entre cultivares de mamoneira por meio de marcadores RAPD. Pesquisa Agropecu. Bras. 48: 342-345. http://dx.doi.org/10.1590/S0100$\underline{204 X 2013000300014}$

Maluf WR, Azevedo SM, Gomes LAA and de Oliveira AC (2002). Inheritance of resistance to the root-knot nematode Meloidogyne javanica in lettuce. Genet. Mol. Res. 1: 64-71. http://dx.doi.org/10.4238/vol1-1gmr006

Medina Filho HP, Bordignon R and Carvalho CHS (2008). Desenvolvimento de novas cultivares de café arábica. In: Cultivares de café: origem, características e recomendações (Carvalho CHS, ed.). Brasília: Embrapa Café, 79-102.

Missio RF, Caixeta ET, Zambolim EM, Zambolim L, et al. (2009). Development and validation of SSR markers for Coffea

Genetics and Molecular Research 15 (3): gmr.15038054 
arabica L. Crop Breed. Appl. Biotechnol. 9: 361-371. http://dx.doi.org/10.12702/1984-7033.v09n04a11

Missio RF, Caixeta ET, Zambolim EM, Pena GF, et al. (2011). Genetic characterization of elite coffee germplasm assessed by SSR and EST-SSR markers. Genet. Mol. Res. 10: 2 366-2381.

Noir S, Anthony F, Bertrand B, Combes MC, et al. (2003). Identification of a major gene (Mex-1) from Coffea canephora conferring resistance to Meloidogyne exigua in Coffea arabica. Plant Pathol. 1: 97-103. http://dx.doi.org/10.1046/ j.1365-3059.2003.00795.x

Nunes CF, Ferreira JL, Fernandes MCN, Breves SS, et al. (2011). An improved method for genomic DNA extraction from strawberry leaves. Cienc. Rural 41: 1383-1389. http://dx.doi.org/10.1590/S0103-84782011000800014

Peakall R and Smouse PE (2006). GenAlEx 6: genetic analysis in Excel. Population genetic software for teaching and research. Mol. Ecol. Notes 6: 288-295. http://dx.doi.org/10.1111/j.1471-8286.2005.01155.x

Pereira HS, dos Santos JB, Souza TP and Lima IA (2008). Seleção fenotípica e assistida por marcadores moleculares de famílias de feijoeiro-comum com alta produtividade. Pesquisa Agropecu. Bras. 43: 1551-1558. http://dx.doi. org/10.1590/S0100-204X2008001100014

Pereira TB, Lima SML, Souza ZR, Teixeira BP, et al. (2012). Reação de genótipos de cafeeiro (Coffea arabica L.) a Meloidogyne exigua população Sul de Minas. Coffee Sci. 7: 84-90.

Rovelli P, Mettulio R, Antonhy F, Anzueto F, et al. (2000). Microsatellites in Coffea arabica L. In: International Seminar on Biotechnology in the Coffee Agroindustry, Proceedings 3: 123-133.

Rezende RM, Salgado SM de L, de Rezende JC, Carvalho GR, et al. (2013). Resistance of Coffea arabica progenies in field conditions infested by Meloidogyne exigua. Nematropica 43: 233-240.

Ruan CJ, Li H and Mopper S (2009). Characterization and identification of ISSR markers associated with resistance to dried-shrink disease in sea buckthorn. Mol. Breed. 24: 255-268. http://dx.doi.org/10.1007/s11032-009-9288-5

SAS INSTITUTE (2004). SAS/STAT 9.1 User's Guide, Cary.

Sasser JN (1977). Worldwide dissemination and importance of the root-knot nematodes, Meloidogyne spp. J. Nematol. 9: $26-29$.

Seinhorst JW (1967). The relationships between population increase and population density in plant parasitic nematodes: I., definitions of the terms host, host status and resistance: the influence of external conditions on the regulation of population density. Nematologica 13: 429-450. http://dx.doi.org/10.1163/187529267X00670

Setotaw TA, Caixeta ET, Pena GF, Zambolim EM, et al. (2010). Breeding potential and genetic diversity of "Híbrido do Timor" coffee evaluated by molecular markers. Crop Breed. Appl. Biotechnol. 10: 298-304.

Setotaw TA, Caixeta ET, Pereira AA, Oliveira ACB, et al. (2013). Coefficient of Parentage in Coffea arabica L. Cultivars Grown in Brazil. Crop Sci. 53: 1237-1247. http://dx.doi.org/10.2135/cropsci2012.09.0541

Silva HD and Vencovsky R (2002). Poder de detecção de 'quantitative trait loci' da análise de marcas simples e da regressão linear múltipla. Sci. Agric. 59: 755-762. http://dx.doi.org/10.1590/S0103-90162002000400020

Silva JFV, Ferraz LCBC, Arias CAA and Abdelnoor RV (2001). Identificação de marcadores moleculares microssatélites associados à resistência de genótipos de soja a Meloidogyne javanica. Nematol. Bras. 25: 79-83.

Souza FF, Caixeta ET, Ferrão LFV, Pena GF, et al. (2013). Molecular diversity in Coffea canephora germplasm conserved and cultivated in Brazil. Crop Breed. Appl. Biotechnol. 13: 273-276. http://dx.doi.org/10.1590/S198470332013000400001

Tamura K, Stecher G, Peterson D, Filipski A, et al. (2013). MEGA6: molecular evolutionary genetics analysis: version 6.0. Mol. Biol. Evol. 30: 2725-2729. http://dx.doi.org/10.1093/molbev/mst197

\section{Supplementary material}

Table S1. Sequence and expected allele size (bp) of the microsatellite markers used in this study. 